\title{
Physical, Mechanical and Bonding Performance of Calabrian Pine (Pinus brutia Ten.) as Influenced by Heat Treatment
}

\section{Utjecaj toplinske obrade na fizikalna i mehanička svojstva te na svojstva lijepljenih spojeva drva kalabrijskog bora (Pinus brutia Ten.)}

\author{
Original scientific paper • Izvorni znanstveni rad \\ Received-prispjelo: 8. 9. 2015. \\ Accepted-prihvaćeno: 15. 11. 2016. \\ UDK: $630 * 812.463 ; 630 * 812.7 ; 674.032 .475 .44 ; 630 * 824.44$ \\ doi:10.5552/drind.2017.1533
}

\begin{abstract}
In this study, the effects of heat treatment on some physical, mechanical, wettability and bonding properties of Calabrian pine (Pinus brutia Ten.) were investigated. Specimens were exposed to heat under atmospheric pressure at four different temperatures $\left(120,150,180,210^{\circ} \mathrm{C}\right)$ and three different time levels $(2$, 5,8 hours). Weight loss, bending strength (MOR), modulus of elasticity (MOE) in bending, Young's modulus in compression, compression strength parallel to grain, contact angle, and bonding performance using shear tests were evaluated. All of the properties of the specimens tested were affected by heat treatment of different intensity. As a result, softer treatments yielded some increase in mechanical properties, but increase of time and temperature resulted in significant decrease in mechanical properties with decreasing mass loss. Contact angle measurements before and after treatment indicated a significant increase in wood hydrophobicity. Shear strength of the specimens were diminished when time and temperature of heat treatment were increased.
\end{abstract}

Key words: Calabrian pine, heat treatment, mechanical properties, bonding

SAŽETAK・U radu su prikazani rezultati istraživanja učinaka toplinske obrade na neka fizikalna i mehanička svojstva, sposobnost kvašenja i svojstva lijepljenih spojeva drva kalabrijskog bora (Pinus brutia Ten.). Uzorci su izloženi utjecaju topline pod atmosferskim tlakom pri četiri različite temperature $\left(120,150,180\right.$ i $\left.210{ }^{\circ} \mathrm{C}\right)$ i tri različita vremena izlaganja (2, 5 i 8 sati). Primjenom smičnih testova određeni su gubitak mase, čvrstoća na savijanje (MOR), modul elastičnosti (MOE) pri savijanju, Youngov modul pri tlačnom opterećenju, tlačna čvrstoća paralelno s vlakancima, kontaktni kut i svojstva lijepljenog spoja. Toplinska obrada drva utjecala je na sva istraživana svojstva uzoraka kalabrijskog bora, ali je taj utjecaj bio različitog intenziteta. Rezultati su pokazali da blaži uvjeti toplinske obrade neznatno pridonose povećanju vrijednosti mehaničkih svojstava, a porast vremena i temperature toplinske obrade

\footnotetext{
${ }^{1}$ Authors are associate professor, research assistant and associate professor at Department of Forest Products Engineering, Faculty of Forestry, Suleyman Demirel University, Isparta, Turkey.

Autori su izvanredni profesor, asistent i izvanredni profesor Odjela za inženjerstvo drvnih proizvoda, Šumarski fakultet, Sveučilište Suleyman Demirel, Isparta, Turska.
} 
rezultirali su značajnim smanjenjem vrijednosti mehaničkih svojstava i smanjenjem gubitka mase. Mjerenje kontaktnog kuta na površini uzoraka prije i nakon toplinske obrade pokazalo je značajan porast hidrofobnosti drva. Pri povećanju vremena i temperature toplinske obrade smanjila se smična čvrstoća uzoraka.

Ključne riječi: kalabrijski bor, toplinska obrada, mehanička svojstva, lijepljenje

\section{INTRODUCTION}

\section{UVOD}

Preservation of wood using heat-treatment process is one of the modification processes that alter the physical, chemical and mechanical properties of wood. Studies on heat treatment of wood are not new. They started in the 1920s by Tiemann and gained interest in the last two decades leading to commercialization (Esteves and Pereira, 2009). According to Boonstra (2008), the reasons for this interest may include decreasing of durable timber, increasing demand of sustainable building materials, deforestation of sub-tropical forests and restrictive regulations. In the heat-treatment process, wood is exposed to temperatures up to $160-250^{\circ} \mathrm{C}$, usually above 200 ${ }^{\circ} \mathrm{C}$ depending on the species used and the desired material properties (Kocaefe et al., 2008).

While thermal treatment of wood results in darkened color, decreased moisture performance, improved biological durability and improved dimensional stability, most of its mechanical properties will decrease depending upon species tested, temperature and duration of exposure (Esteves and Pereira, 2009). During the process, hemicelluloses are the first to decompose, then lignin softens and finally cellulose and hydrophilic groups are modified (Bekhta and Niemz, 2003). Since hardwoods contain higher proportion of hemicelluloses than softwoods, the degradation is more severe (Esteves et al., 2007).

Different commercial treatments appeared due to the increase of demand for heat treated wood in different countries during the last two decades. Increase in demand also resulted in the number of investigations conducted on different wood species. Some selected properties of heat treated wood species can be found in Esteves and Pereira (2009), but in general, color change, equilibrium moisture content (EMC), dimensional stability, bending properties and compression strength were studied in most investigations.

The purpose of this study was to investigate the influence of the heat treatment on some physical, mechanical, wettability as well as bonding performance of Calabrian pine wood. The effect of heat treatment on physical and mechanical properties of wood is wellunderstood, but investigations on wettability and bonding behavior are scarce. Calabrian pine covers the largest area (3 096064 ha) among conifers grown in Turkey, which corresponds to approximately $15 \%$ of the total forest area. Calabrian pine is a fast-growing tree; its wood is an important raw material for various fields, including construction (Bektas et al. 2003).

\section{MATERIALS AND METHODS}

2. MATERIJALI I METODE

Small clear wood samples were prepared from Calabrian pine (Pinus brutia Ten.) logs harvested from Bucak Forest District in Turkey. They were approxi- mately $50 \mathrm{~cm}$ in diameter. The logs were transferred and sawn to lumber. Only sapwood lumbers were used in order to prepare small clear specimens.

Three pieces $(2,5,8$ hours) of lumber, free of visible defects, were used in preparation of each individual test. Five matched heat treatment samples $(0,120$, $150,180,210{ }^{\circ} \mathrm{C}$ ), with the dimensions $20 \times 80 \times 480$ $\mathrm{mm}$, were cut from each lumber. Specimens were exposed to heat under atmospheric pressure. For shear tests, PVA adhesive was used. After heat treatment, small samples were cut for testing. At least 6 replicates were prepared for each test group.

Before testing and after heat treatment process, specimens were conditioned in climatic chambers at 65 $\%$ relative humidity $(\mathrm{RH})$ at a temperature of $20^{\circ} \mathrm{C}$. To minimize the influence of the $\mathrm{MC}$ change, specimens were tested immediately after removal from the climatic chamber. Wood MC was determined by the oven-drying method. Apparent densities of the samples were calculated according to TS 2472 (2005) using stereometric method, which is based on measurement of the sample volume and mass. The properties of wood samples investigated include mass loss (ML, \%), bending modulus of elasticity (MOE), bending strength (MOR), compression strength (CS), Young's modulus in compression (YM), contact angle using water (CAW), contact angle using hexane (CAH) and shear strength (SS).

Weight loss was measured by the difference of dry weight before and after thermal treatments. Mechanical tests were performed using UTM with the capacity of 50 $\mathrm{kN}$. Static bending tests were performed in a three-point bending apparatus with a span length of $360 \mathrm{~mm}$ and a loading speed of $6 \mathrm{~mm} / \mathrm{min}$, according to TS 2474 (1976) and 2478 (1976). Compression tests were conducted using an extensometer with a loading speed of 2 $\mathrm{mm} /$ minute according to TS 2595 (1997). Shear tests were performed according to TS 3459 (2012). After the mechanical tests, the load-deflection curves were analyzed in order to calculate the mechanical properties. The contact angles of water and hexane droplets on untreated and heat-treated samples were measured by the sessile drop method in the grain of sapwood cut in tangential surfaces using KSV-CAM 101 tensiometer. Hexane was chosen as non-polar test liquid to avoid problems due to polarity of wood. All measurements were performed at $20{ }^{\circ} \mathrm{C}$ and $65 \%$ relative humidity.

Analysis of variance (ANOVA) general linear model procedure was run for data with SAS statistical analysis software to interpret effects of temperature and duration of exposure on the properties of clear wood samples.

\section{RESULTS AND DISCUSSION}

3. REZULTATI I RASPRAVA

Average values for ML, MOE, MOR, CS, YM, $\mathrm{CAW}, \mathrm{CAH}$ and SS of the specimens tested are pre- 
sented in Table 1. The average density of the control samples were $0.54 \mathrm{~g} / \mathrm{cm}^{3}$ with a correlation coefficient of $11 \%$. There was a good match among the density values in the various treatment groups. With respect to available literature references for similar $\mathrm{MC}$, the measured density values were comparable.

ML values (\%) of the specimens tested are presented in Figure 1 and ranged between $0.80 \%$ and $15.97 \%$, depending on the temperature and duration of exposure. The values of ML (\%) are accumulated with increasing temperature and duration of exposure. The values found in this study are similar to those reported by Esteves and Pereira (2009). ML is mainly due to the degradation of the hemicelluloses, which are the most heat sensitive polymers of the wood (Bourgois and Guyonnet, 1988). Mass loss is also one of the most important aspects of heat treatment and is accepted as indication of quality (Esteves and Pereira, 2009).

In general, the change of mechanical properties depends on the tree species and on conditions of the heat treatment. Bending properties of the samples tested in this study were significantly affected by heat treatment.
MOE seemed to increase for softer treatments (\%) and decrease for more severe treatments as shown in Figure 2. Results indicate that 2-hour heat treatment of samples increased the MOE values of the samples by $6 \%$, while 8-hour treatment decreased the MOE values by $7.8 \%$. There is no significant difference between the MOE values of control samples and 5-hour treatments.

There is no significant difference between the MOR values of the control samples and 2-hour treatments. For the 5 hour treatments, the MOR values of the samples were increased by $5 \%$ and $3 \%$ when the temperature was raised to 120 and $150{ }^{\circ} \mathrm{C}$, while 180 and $210{ }^{\circ} \mathrm{C}$ exposures decreased the MOR values by $5 \%$ and $7 \%$, respectively. After 8-hour heat treatment, the MOR values of the samples were increased by $5 \%$ and $8 \%$ when the temperature was raised to 120 and $150{ }^{\circ} \mathrm{C}$, while 180 and $210^{\circ} \mathrm{C}$ exposures decreased the MOR values by $7 \%$ and $55 \%$, respectively. Influence of heat treatments on the MOR values is shown in Figure 3.

The effect of heat treatment on the MOR values of the wood is greater than on the MOE values (Esteves and Pereira, 2009; and Ross, 2010). According to Esteves and Pereira (2009), softer heat treatments yield

Table 1 Average values of ML, MOE, MOR, YM, CS, SS, CAW and CAH

Tablica 1. Prosječne vrijednosti veličina ML, MOE, MOR, YM, CS, SS, CAW i CAH

\begin{tabular}{|c|c|c|c|c|c|c|c|c|c|}
\hline $\begin{array}{c}\text { Temp } \\
{ }^{\circ} \mathrm{C}\end{array}$ & Hour & $\begin{array}{c}\text { ML } \\
\%\end{array}$ & $\begin{array}{c}\text { MOE } \\
\text { N/mm }{ }^{2}\end{array}$ & $\begin{array}{l}\text { MOR } \\
\text { MPa }\end{array}$ & $\begin{array}{c}\text { YM } \\
\text { MPa }\end{array}$ & $\begin{array}{c}\text { CS } \\
\text { MPa }\end{array}$ & $\begin{array}{c}\text { SS } \\
\text { MPa }\end{array}$ & 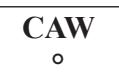 & $\underset{\circ}{\text { CAH }}$ \\
\hline \multirow{3}{*}{ Control } & $2 *$ & 0 & $\begin{array}{c}8181 \\
(9.93)^{* *}\end{array}$ & $\begin{array}{c}102 \\
(7.41) \\
\end{array}$ & $\begin{array}{c}10111 \\
(14.46) \\
\end{array}$ & $\begin{array}{c}52 \\
(5.39) \\
\end{array}$ & $\begin{array}{c}8.45 \\
(10.48) \\
\end{array}$ & $\begin{array}{c}60.49 \\
(23.14) \\
\end{array}$ & $\begin{array}{c}13.87 \\
(48.22) \\
\end{array}$ \\
\hline & $5^{*}$ & 0 & $\begin{array}{l}12365 \\
(9.16)\end{array}$ & $\begin{array}{c}136 \\
(7.37)\end{array}$ & $\begin{array}{l}17093 \\
(9.03)\end{array}$ & $\begin{array}{c}74 \\
(2.51)\end{array}$ & $\begin{array}{c}8.45 \\
(10.48)\end{array}$ & $\begin{array}{c}45.66 \\
(20.52)\end{array}$ & $\begin{array}{c}13.65 \\
(40.24)\end{array}$ \\
\hline & $8^{*}$ & 0 & $\begin{array}{c}10519 \\
(13.54)\end{array}$ & $\begin{array}{c}114 \\
(9.99)\end{array}$ & $\begin{array}{c}13022 \\
(13.07)\end{array}$ & $\begin{array}{c}53 \\
(10.31)\end{array}$ & $\begin{array}{c}8.45 \\
(10.48)\end{array}$ & $\begin{array}{c}31.20 \\
(35.11)\end{array}$ & $\begin{array}{c}13.48 \\
(50.63)\end{array}$ \\
\hline 120 & \multirow{4}{*}{2} & $\begin{array}{c}0.8 \\
(4.75)\end{array}$ & $\begin{array}{c}9012 \\
(7.79)\end{array}$ & $\begin{array}{c}105 \\
(10.17)\end{array}$ & $\begin{array}{l}13595 \\
(23.78)\end{array}$ & $\begin{array}{c}57 \\
(10.09)\end{array}$ & $\begin{array}{c}6.87 \\
(8.81)\end{array}$ & $\begin{array}{c}68.96 \\
(35.11)\end{array}$ & $\begin{array}{c}13.16 \\
(35.07)\end{array}$ \\
\hline 150 & & $\begin{array}{c}1.5 \\
(4.2)\end{array}$ & $\begin{array}{c}8537 \\
(10.53)\end{array}$ & $\begin{array}{c}101 \\
(5.57)\end{array}$ & $\begin{array}{c}11242 \\
(13.74)\end{array}$ & $\begin{array}{c}54 \\
(7.81)\end{array}$ & $\begin{array}{c}9.96 \\
(6.96)\end{array}$ & $\begin{array}{c}66.54 \\
(7.06)\end{array}$ & $\begin{array}{c}11.62 \\
(39.44)\end{array}$ \\
\hline 180 & & $\begin{array}{l}1.81 \\
(7.1)\end{array}$ & $\begin{array}{c}8034 \\
(9.48)\end{array}$ & $\begin{array}{c}103 \\
(11.02)\end{array}$ & $\begin{array}{l}11114 \\
(8.86)\end{array}$ & $\begin{array}{c}57 \\
(3.69)\end{array}$ & $\begin{array}{c}6.99 \\
(8.59)\end{array}$ & $\begin{array}{c}79.13 \\
(20.42)\end{array}$ & $\begin{array}{c}12.46 \\
(51.58)\end{array}$ \\
\hline 210 & & $\begin{array}{c}9.42 \\
(2.12)\end{array}$ & $\begin{array}{l}9296 \\
(9.71)\end{array}$ & $\begin{array}{c}103 \\
(9.10)\end{array}$ & $\begin{array}{l}16659 \\
(12.15)\end{array}$ & $\begin{array}{c}67 \\
(8.79)\end{array}$ & $\begin{array}{c}2.75 \\
(13.00)\end{array}$ & $\begin{array}{c}100 \\
(5.12)\end{array}$ & $\begin{array}{c}8.89 \\
(30.24)\end{array}$ \\
\hline 120 & \multirow{4}{*}{5} & $\begin{array}{c}2.05 \\
(5.85)\end{array}$ & $\begin{array}{l}13584 \\
(7.39)\end{array}$ & $\begin{array}{c}165 \\
(7.37)\end{array}$ & $\begin{array}{c}20104 \\
(10.39)\end{array}$ & $\begin{array}{c}75 \\
(14.33)\end{array}$ & $\begin{array}{c}5.96 \\
(44.22)\end{array}$ & $\begin{array}{c}71 \\
(33.53)\end{array}$ & $\begin{array}{c}12.19 \\
(52.43)\end{array}$ \\
\hline 150 & & $\begin{array}{l}2.13 \\
(3.4)\end{array}$ & $\begin{array}{c}11779 \\
(10.96)\end{array}$ & $\begin{array}{c}160 \\
(6.26)\end{array}$ & $\begin{array}{c}16233 \\
(12.53)\end{array}$ & $\begin{array}{c}77 \\
(8.21)\end{array}$ & $\begin{array}{c}8.07 \\
(14.80)\end{array}$ & $\begin{array}{c}89.29 \\
(11.19)\end{array}$ & $\begin{array}{c}11.18 \\
(57.32)\end{array}$ \\
\hline 180 & & $\begin{array}{l}3.04 \\
(4.5)\end{array}$ & $\begin{array}{c}11786 \\
(10.70)\end{array}$ & $\begin{array}{c}122 \\
(4.10)\end{array}$ & $\begin{array}{l}15819 \\
(14.54)\end{array}$ & $\begin{array}{c}74 \\
(6.30)\end{array}$ & $\begin{array}{c}6.57 \\
(19.06)\end{array}$ & $\begin{array}{l}93.26 \\
(5.59)\end{array}$ & $\begin{array}{c}9.84 \\
(48.43)\end{array}$ \\
\hline 210 & & $\begin{array}{l}11.53 \\
(3.5)\end{array}$ & $\begin{array}{c}10939 \\
(11.59)\end{array}$ & $\begin{array}{c}105 \\
(6.88)\end{array}$ & $\begin{array}{c}12630 \\
(14.18)\end{array}$ & $\begin{array}{c}65 \\
(12.57)\end{array}$ & $\begin{array}{c}3.15 \\
(18.60)\end{array}$ & $\begin{array}{l}111.15 \\
(5.57)\end{array}$ & $\begin{array}{c}9.82 \\
(27.29)\end{array}$ \\
\hline 120 & \multirow{4}{*}{8} & $\begin{array}{l}2.85 \\
(6.5) \\
\end{array}$ & $\begin{array}{l}10433 \\
(9.81) \\
\end{array}$ & $\begin{array}{c}115 \\
(6.41) \\
\end{array}$ & $\begin{array}{l}14156 \\
(10.47) \\
\end{array}$ & $\begin{array}{c}59 \\
(5.22) \\
\end{array}$ & $\begin{array}{c}12.28 \\
(16.13) \\
\end{array}$ & \begin{tabular}{|c|}
83.88 \\
$(18.51)$ \\
\end{tabular} & $\begin{array}{c}11.39 \\
(37.13) \\
\end{array}$ \\
\hline 150 & & $\begin{array}{c}3.49 \\
(5.15)\end{array}$ & $\begin{array}{c}10182 \\
(12.09) \\
\end{array}$ & $\begin{array}{c}113 \\
(14.31) \\
\end{array}$ & $\begin{array}{c}13337 \\
(12.74) \\
\end{array}$ & $\begin{array}{c}58 \\
(11.24) \\
\end{array}$ & $\begin{array}{c}7.68 \\
(17.90) \\
\end{array}$ & $\begin{array}{l}114.91 \\
(11.76)\end{array}$ & $\begin{array}{c}10.23 \\
(47.18) \\
\end{array}$ \\
\hline 180 & & $\begin{array}{l}7.56 \\
(3.0) \\
\end{array}$ & $\begin{array}{c}9964 \\
(9.25)\end{array}$ & $\begin{array}{c}104 \\
(7.57)\end{array}$ & $\begin{array}{l}12414 \\
(9.32)\end{array}$ & $\begin{array}{c}61 \\
(6.47)\end{array}$ & $\begin{array}{c}4.92 \\
(19.28)\end{array}$ & $\begin{array}{l}104.28 \\
(3.58)\end{array}$ & $\begin{array}{c}9.50 \\
(39.62)\end{array}$ \\
\hline 210 & & $\begin{array}{c}15.97 \\
(15)\end{array}$ & $\begin{array}{c}9099 \\
(5.79)\end{array}$ & $\begin{array}{c}51 \\
(10.12) \\
\end{array}$ & $\begin{array}{c}11145 \\
(11.70) \\
\end{array}$ & $\begin{array}{c}52 \\
(9.88) \\
\end{array}$ & $\begin{array}{c}2.38 \\
(10.43) \\
\end{array}$ & $\begin{array}{l}87.50 \\
(5.12) \\
\end{array}$ & $\begin{array}{c}9.79 \\
(20.08)\end{array}$ \\
\hline
\end{tabular}

ML - mass loss, \% / gubitak mase, \%; MOE - bending modulus of elasticity / modul elastičnosti pri savijanju; MOR - bending strength / čvrstoća na savijanje; YM - Young's modulus in compression / Youngov modul pri tlačnom opterećenju; CS - compression strength / tlačna čvrstoća; SS - shear strength / smična čvrstoća; CAW - contact angle using water / kontaktni kut primjenom vode; CAH - contact angle using hexane / kontaktni kut primjenom heksana; * number indicates piece of lumber from which samples were made, not hours of treatment duration / broj označava uzorak piljenice od koje su izrađeni uzorci, a ne vrijeme trajanja toplinske obrade; **values in parenthesis are coefficient of variations / vrijednosti u zagradama označuju koeficijent varijacije 


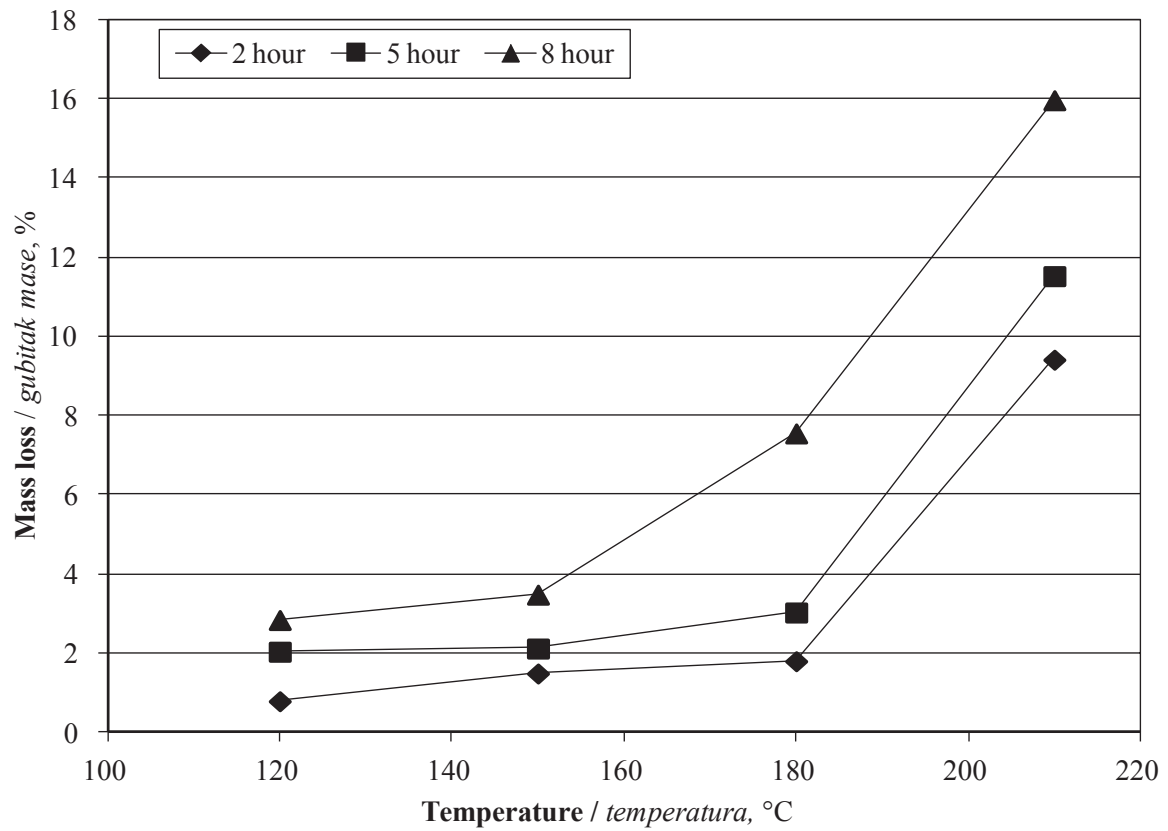

Figure 1 Effect of heat treatment on ML (\%) of Calabrian pine

Slika 1. Utjecaj toplinske obrade drva kalabrijskog bora na gubitak mase

an increase in the MOE values, while severe treatments result in a decrease in the MOE values. The findings presented by Altınok et al. (2010) support this idea. Kubojima et al. (2000) state that the effects of heat treatment on the MOR are less in nitrogen than in air.

Figure 4 presents the effects of heat treatment on the YM values. Test results show that 2 hour-treatments increase the YM values by $20 \%$, while 5 hour-treatments decrease the YM values by $23 \%$. There is no significant difference between the values of control samples and 8 -hour treatments. There is no significant difference between the values of control samples and $150-180{ }^{\circ} \mathrm{C} \mathrm{ex}-$ posures. Kubojima et al. (1998) reported similar results for Sitka spruce exposed to 120,160 , and $200^{\circ} \mathrm{C}$. According to Kubojima et al. (1998), the increase in the YM can be explained by the increase in the crystallinity index of cellulose, while the decrease is due to the degradation.

Figure 5 illustrates the effects of heat treatment on the CS values. Results indicate that 2 and 8 -hour treatments increase the CS values by $10 \%$ and $14 \%$, respectively, while 5-hour treatments decrease the CS values by $14 \%$ in comparison to control samples.

There is a contradiction in the literature on whether the CS is decreased by heat treatment or not.

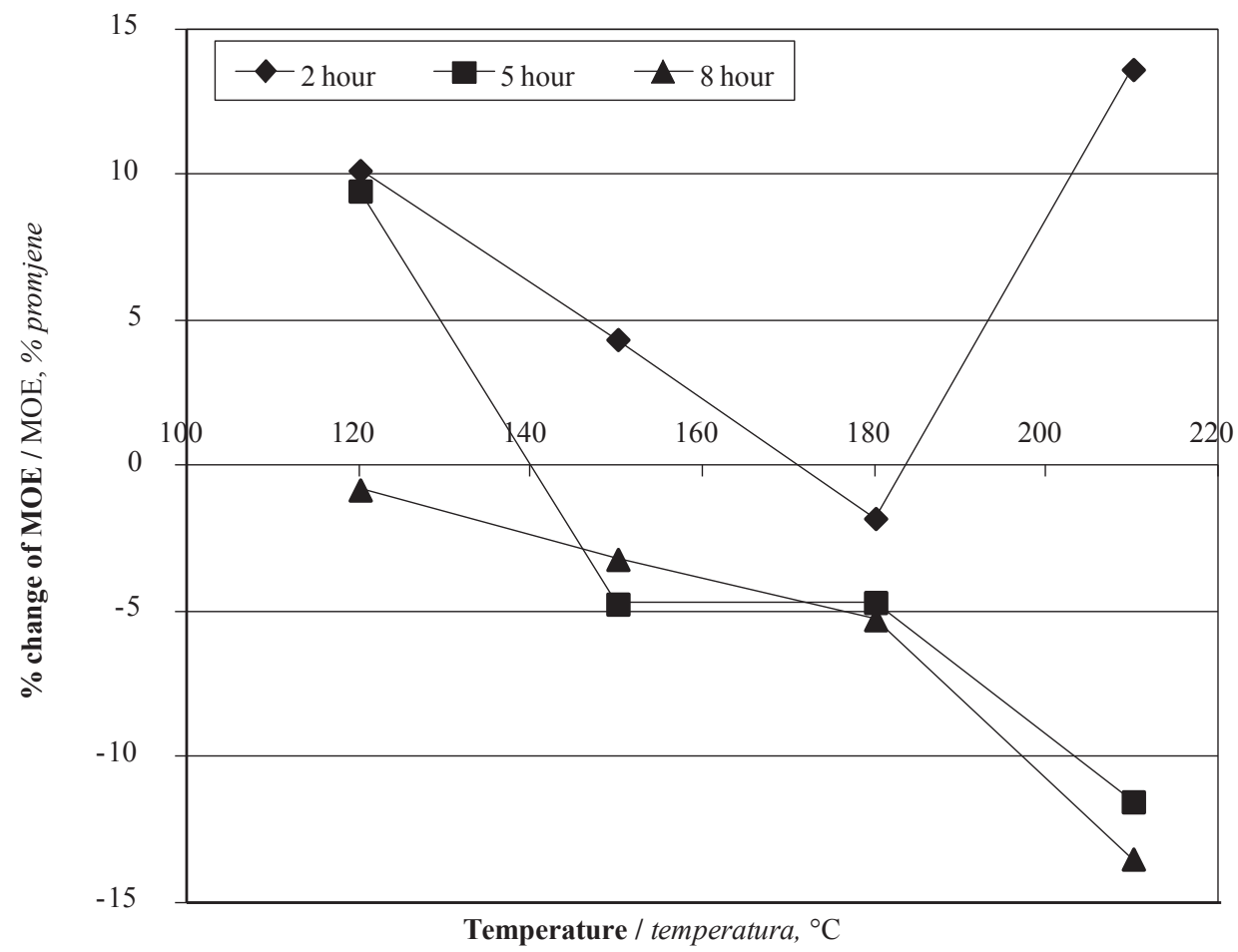

Figure 2 Effect of heat treatment on MOE values of Calabrian pine

Slika 2. Utjecaj toplinske obrade drva kalabrijskog bora na modul elastičnosti pri savijanju 


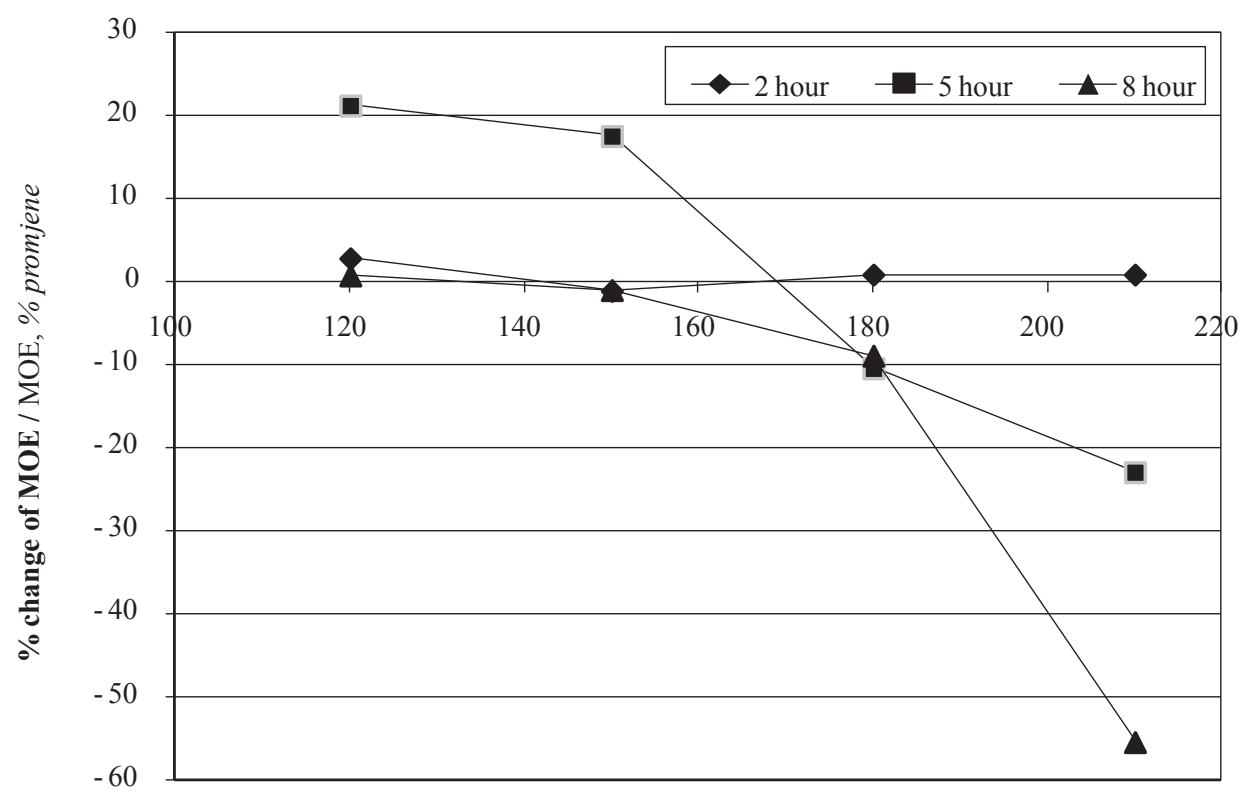

Temperature / temperatura, ${ }^{\circ} \mathrm{C}$

Figure 3 Effect of heat treatment on MOR values of Calabrian pine

Slika 3. Utjecaj toplinske obrade drva kalabrijskog bora na čvrstoću na savijanje

Some authors (Ünsal and Ayrılmış, 2005; Korkut et al., 2008a; Korkut et al., 2008b) found that the CS is decreased by heat treatment, while others (Boonstra and Blomberg, 2007; Altınok et al., 2010) reported an increase with heat treatment.

The reduction of mechanical properties due to heat treatment can be explained by the degradation of hemicelluloses, as the main reason, followed by crystallization of amorphous cellulose. Cross-linking of lignin may contribute to the mechanical properties in the longitudinal direction. The lower equilibrium moisture content may have positive effects on strength properties, but degradation of chemical compounds ousts this effect (Esteves and Pereira, 2009).

While the influence of heat treatment on the physical and mechanical behavior of wood is relatively well known (Esteves and Pereira, 2009), investigations of the wettability and bonding performance are limited. So far, only a few studies have investigated the wettability and bonding performance of wood (Kocaefe et al., 2008; Sernek et al., 2008; Altınok et al., 2010; Perçin and Uzun, 2014).

Heat-treated wood shows lower affinity to water and a strongly modified wettability leading to important changes of its behavior with most coating or gluing processes (Petrissans et al., 2003). According to Hakkou et al. (2005), wood is totally hydrophilic with a contact angle value near zero for heat treatments below $120^{\circ} \mathrm{C}$; after this threshold value, contact angle suddenly changes to reach $90^{\circ}$ for treatment temperature between 120 and $160^{\circ} \mathrm{C}$; for higher temperatures, it remains constant near $90^{\circ}$. Oliveira et al. (2010) state that contact angle also varies for sapwood and heartwood.

Results of this study show that the contact angle using both water and hexane was significantly changed for all treatments, but the change was drastic when hig-

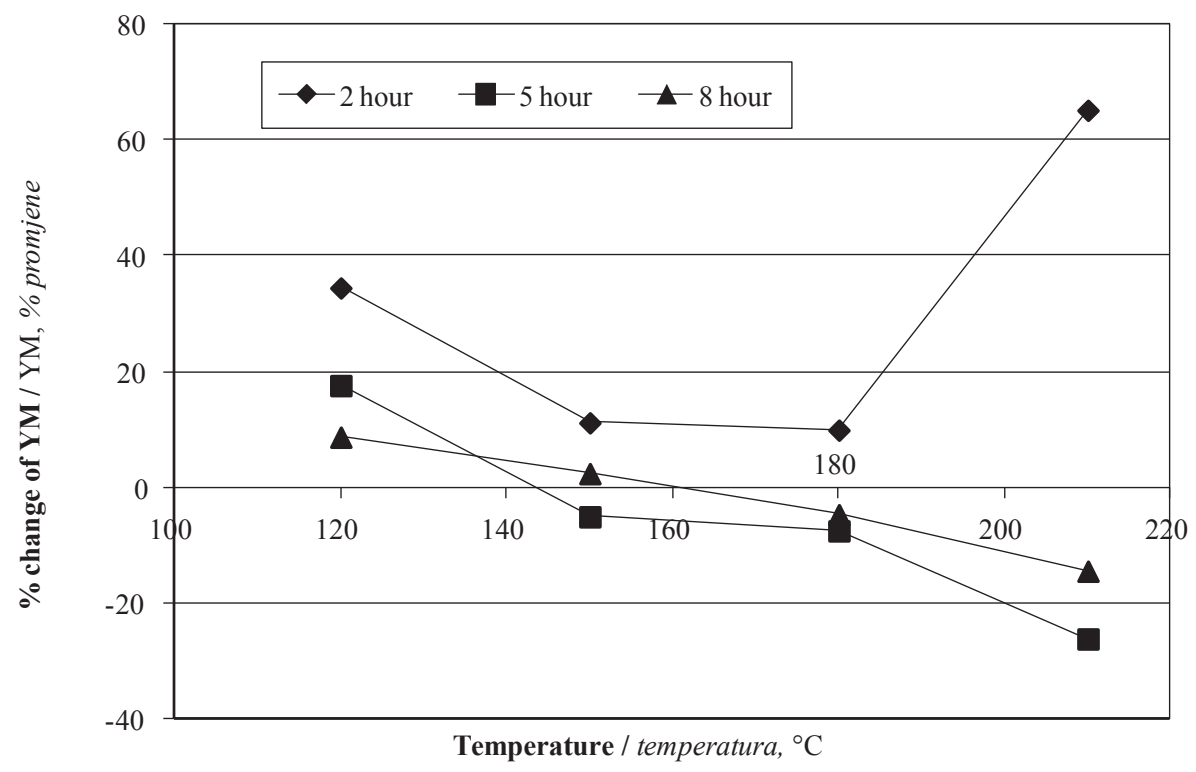

Figure 4 Effect of heat treatment on YM values of Calabrian pine

Slika 4. Utjecaj toplinske obrade drva kalabrijskog bora na Youngov modul pri tlačnom opterećenju 


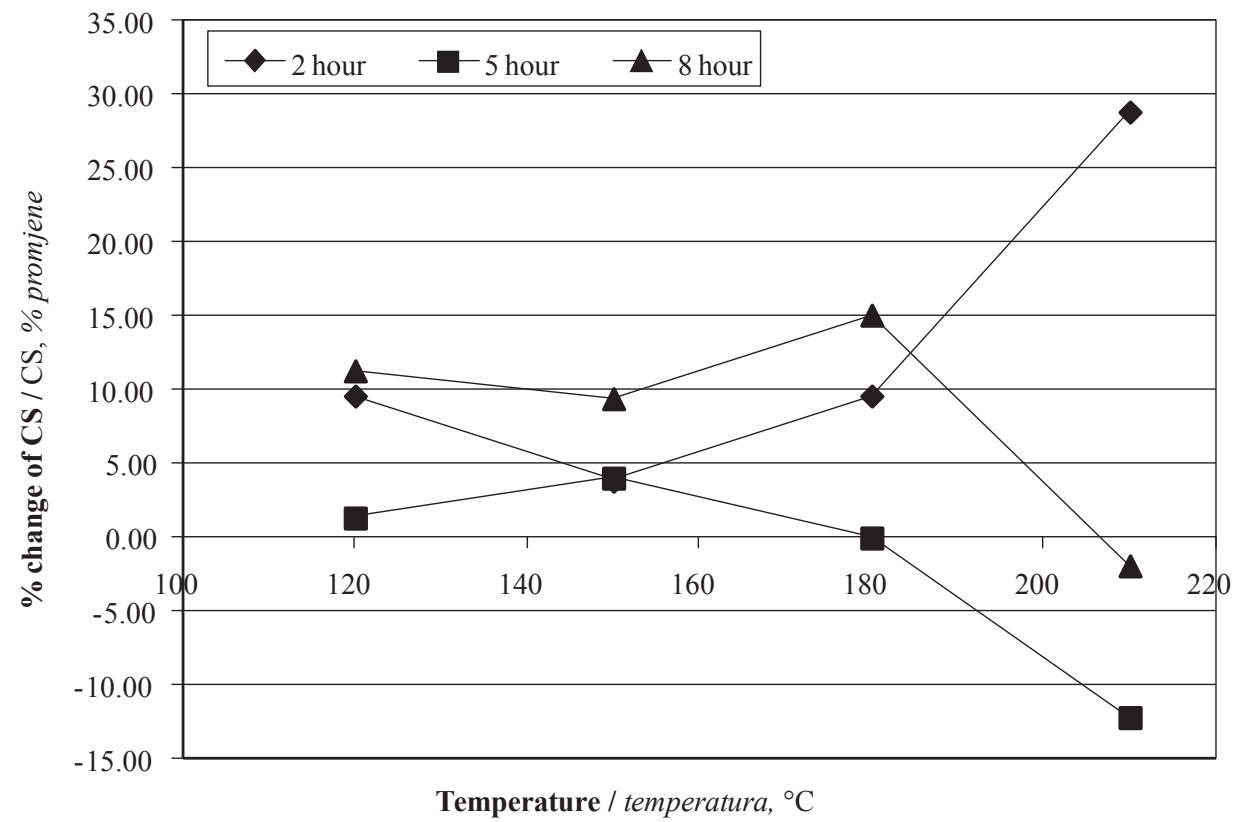

Figure 5 Effect of heat treatments on CS of Calabrian pine

Slika 5. Utjecaj toplinske obrade drva kalabrijskog bora na tlačnu čvrstoću

her temperatures were applied for a longer time (Figure 6 and 7). Generally, the contact angle using water drops is increasing from 120 to $210^{\circ} \mathrm{C}$ due to a higher hydrophobic condition of the wood sample, when higher temperatures are applied for a longer time. The contact angle decreases after $150{ }^{\circ} \mathrm{C}$, thus evidencing that the wood recovers its hydrophilic nature. Treatments between 200 and $260^{\circ} \mathrm{C}$ can cause significant degradation in hemicelluloses content of wood, which release a great content of acetic acid (Weiland et al., 1998). The phenolic carboxylic acid and 4-O-methyl-glucuronic and galacturonic acids, produced as a result of the hydrolysis of wood, also contribute to wood acidity (Windeisen et al., 2007). Chen et al. (2012) state that heat treatment in oxygen leads to lower $\mathrm{pH}$ values than in nitrogen. Production of acid groups in heat treated wood for longer durations and high temperatures may cause a decrease in the contact angle when polar water drops are used. Polar water may form new linkages with acidic functional groups on the surface of heat treated wood. Drying defects occurring on the surface of the samples may enhance watersurface interaction, resulting in a decrease of the contact angle (Oliveira et al. 2010).

Thermal decomposition of hemicelluloses and cellulose of wood with the thermal treatment may lead to reduce the wettability of wood. Decreasing effect of heat treatment on the wettability was also observed by Hakkou et al. (2005) and Kocaefe et al. (2008). Petrissans et al. (2003) suggested that one of the possible reasons for the decrease of wettability could be the increase of cellulose crystallinity.

Results of this study reveal that bonding performance of 2-5-8 hour treated samples were decreased by 20-34 \% comparing to control samples. When $120{ }^{\circ} \mathrm{C}$ exposure was applied, the bonding strength of the samples did not change significantly. $150{ }^{\circ} \mathrm{C}$ exposure seems to increase the bonding strength, but $180^{\circ} \mathrm{C}$ and $210{ }^{\circ} \mathrm{C}$ exposures drastically reduced the bonding

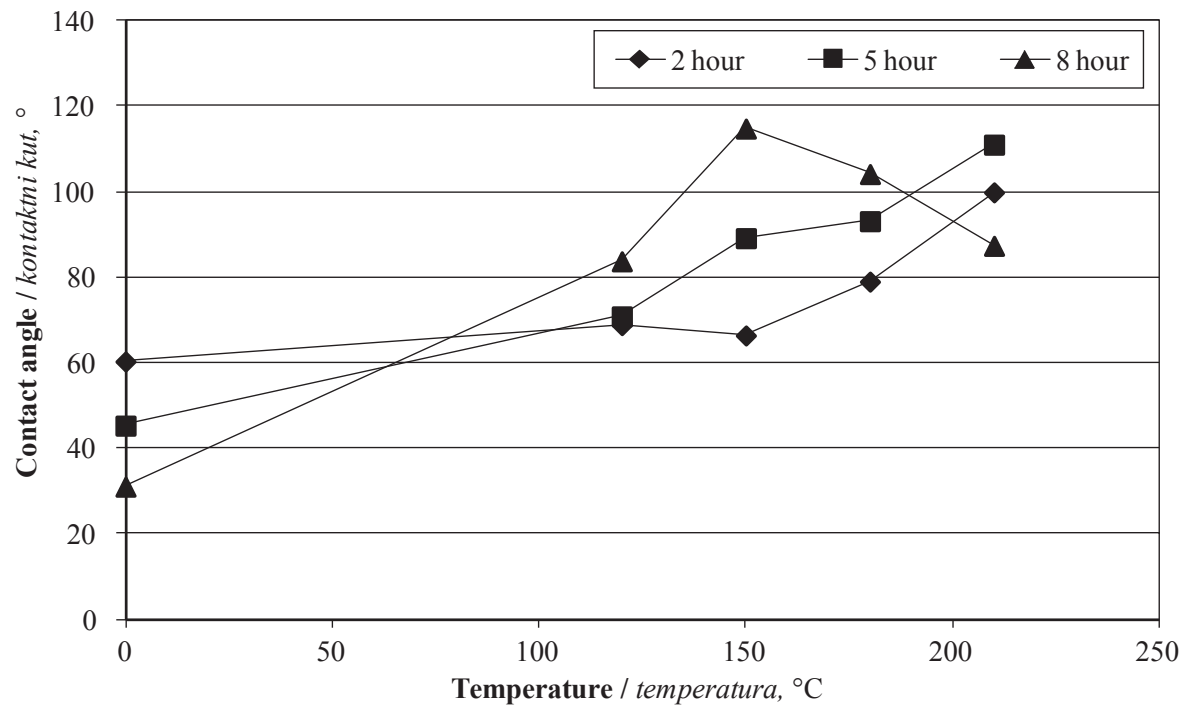

Figure 6 Effects of heat treatment on contact angle measured by water drops

Slika 6. Utjecaj toplinske obrade drva kalabrijskog bora na kontaktni kut izmjeren kapljicama vode 


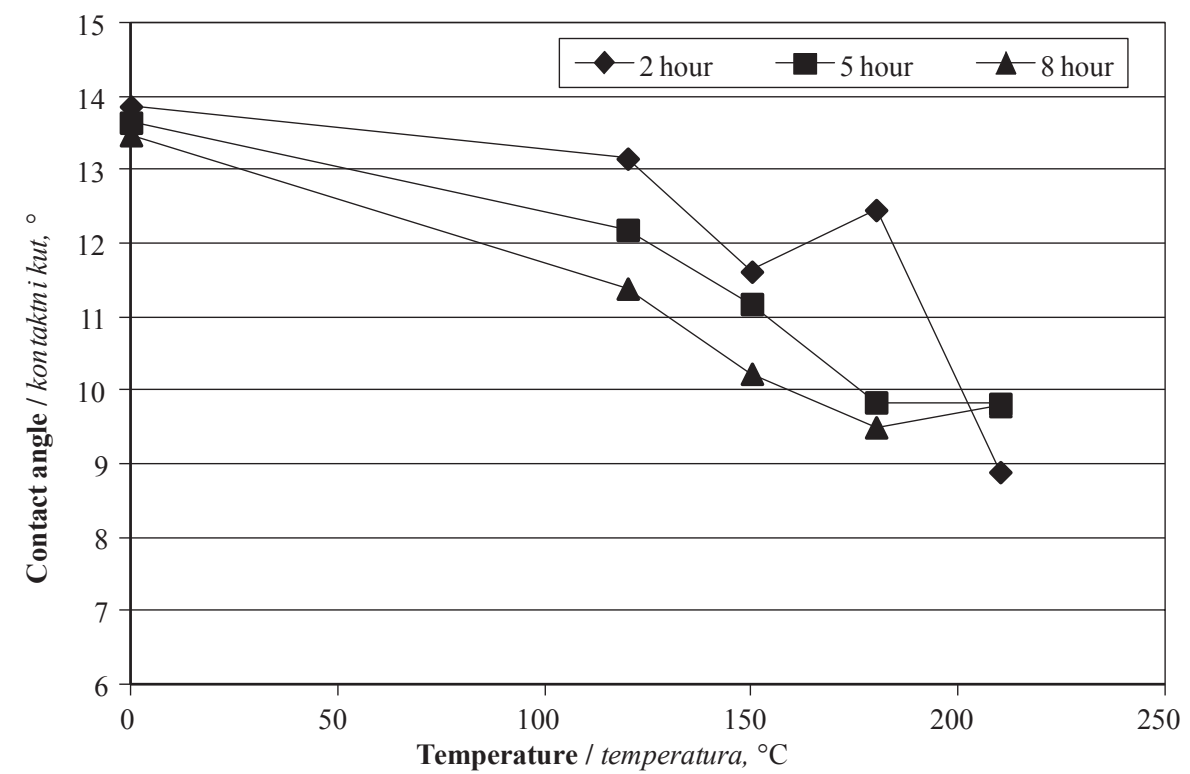

Figure 7 Effects of heat treatment on contact angle measured by hexane drops

Slika 7. Utjecaj toplinske obrade drva kalabrijskog bora na kontaktni kut izmjeren kapljicama heksana

strength $(30 \%$ and $67 \%)$. Figure 8 shows the change in bonding strength depending upon heat treatment duration and temperatures.

Decrease in shear strength was reported by several studies including Šernek et al. (2007), who reported a decline of $13 \%$ for spruce bonded with PF and UF, each by heat treatment at $210{ }^{\circ} \mathrm{C}$ for 2 hours. Another study by Šernek et al. (2008) reported that shear strength was decreased by $23 \%$ for heat treated spruce. Kol et al. (2009) also presented lower shear strength for heat treated Tali and Iroko woods at $180{ }^{\circ} \mathrm{C}$ for 2 hours. Perçin and Uzun (2014) reported similar reduction of bonding strength after heat treatment for wood species of pine, beech, scots pine and poplar using PVAc-D4 type adhesives. Esen and Özcan (2012) presented similar reduction of bonding strength after heat treatment for wood species of oak using several types of adhesives.

The only study that revealed an increase was reported by Altınok et al. (2010), who applied heat treat- ments at 100 and $150{ }^{\circ} \mathrm{C}$ for 4 hours on PVA and PU bonded samples.

\section{CONCLUSIONS \\ 4. ZAKLJUČAK}

Increase of duration and temperature during heat treatment results in a significant weight loss, which is one of the quality parameters of the process. Softer treatments resulted in some improvement in mechanical properties, probably due to lower equilibrium moisture content. MOE and Young's modulus decreased significantly under treatment conditions of longer exposure and higher temperature. The effect of heat treatment on MOR is more severe. CS seems to be increasing with treatment severity. Heat treated samples become hydrophobic at the temperature ranging between 120 and $210{ }^{\circ} \mathrm{C}$. Wettability was significantly reduced by heat treatment resulting in lower shear

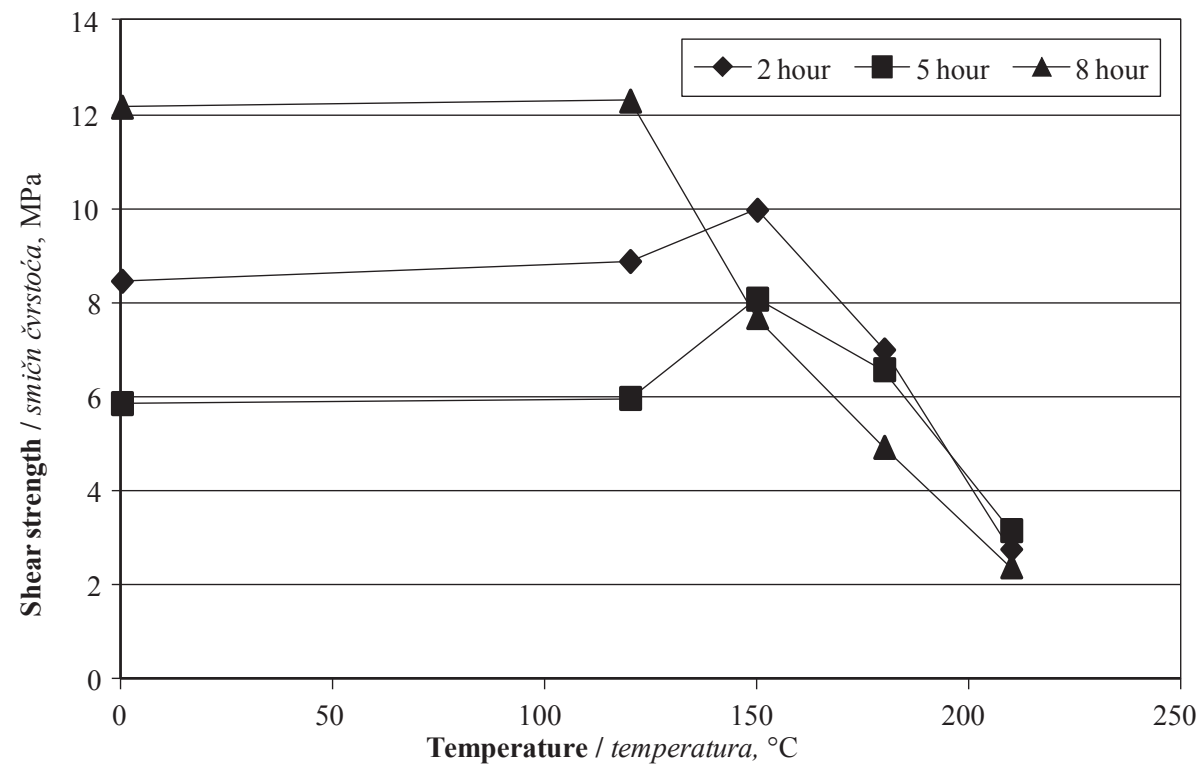

Figure 8 Effect of temperature and duration of exposure on shear strength of Calabrian pine Slika 8. Utjecaj toplinske obrade drva kalabrijskog bora na smičnu čvrstoću 
strength. Since mechanical properties were significantly reduced, heat treated wood of Calabrian pine may not be suitable for load carrying members.

\section{REFERENCES}

\section{LITERATURA}

1. Altınok, M.; Özalp, M.; Korkut, S., 2010: The effects of heat treatment on some mechanical properties of laminated beech (Fagus Orientalis L.) wood. Wood Research, 55 (3): 131-142.

2. Bekhta, P.; Niemz, P., 2003: Effect of high temperature on the changes in color, dimensional stability and mechanical properties of spruce wood. Holzforschung, (57):539-546. http://dx.doi.org/10.1515/HF.2003.080.

3. Bektas, I.; Alma, M. H.; As, N.; Gundogan, R., 2003: Relationship between site index and several mechanical properties of Turkish calabrian pine (Pinus brutia Ten.). Forest Products Journal, 53 (2): 27-31.

4. Boonstra, M., 2008: A two-stage thermal modification of wood. Ph.D. Thesis in Applied Biological Sciences: Soil and Forest management, Henry Poincaré UniversityNancy, France.

5. Boonstra, M.; Blomberg, J., 2007: Semi-isostatic densification of heat-treated radiata pine. Wood Sci. Technol., 41: 607-617. http://dx.doi.org/10.1007/s00226-007-0140-y.

6. Bourgois, J.; Guyonnet, R., 1988: Characterisation and analysis of torrefied wood. Wood Sci. Technol., 22: 143155. http://dx.doi.org/10.1007/BF00355850.

7. Chen, Y.; Fan, Y.; Gao, J.; Stark, N. M., 2012: The effect of heat treatment on the chemical and color change of black locust (Robinia pseudoacacia) wood flour. BioResources, 7 (1): 1157-1170.

8. Esen, R.; Özcan, C., 2012: The effects of heat treatment on shear strength of oak (Quercus petraea L.) wood. SDU Faculty of Forestry Journal, 13: 150-154.

9. Esteves, B.; Domingos, I.; Pereira, H., 2007: Improvement of technological quality of eucalypt wood by heat treatment in air at $170-200{ }^{\circ} \mathrm{C}$. For. Prod. J., 57 (1/2): 47-52.

10. Esteves, B. M.; Pereira, H. M., 2009: Wood modification by heat treatment: A review. BioResources, 48 (1): 370-404.

11. Hakkou, M.; Petrissans, M.; Zoulalian, A.; Gerardin, P., 2005: Investigation of wood wettability changes during heat treatment on the basis of chemical analysis. Polymer Degradation and Stability, 89: 1-5.

http://dx.doi.org/10.1016/j.polymdegradstab.2004.10.017.

12. Kocaefe, D.; Poncsak, S.; Dore, G.; Younsi, R., 2008: Effect of heat treatment on the wettability of white ash and soft maple by water. Holz Roh Werkst, 66: 355-361. http://dx.doi.org/10.1007/s00107-008-0233-9.

13. Kol, H. S.; Özbay, G.; Altun, S., 2009: Shear strength of heat-treated Tali (Erythrophleum ivorense) and Iroko (Chlorophora excelsa) woods, bonded with various adhesives. BioResources, 4 (4): 1545-1554.

14. Korkut, S.; Akgül, M.; Dündar, T., 2008a: The effects of heat treatment on some technological properties of Scots pine (Pinus sylvestris L.) wood. Bioresour. Technol., 99: 1861-1868.

http://dx.doi.org/10.1016/j.biortech.2007.03.038.

15. Korkut, S.; Kök, M.; Korkut, D.; Gürleyen T., 2008b: The effects of heat treatment on technological properties in Red-bud maple (Acer trautvetteri Medw.) wood. Bioresour. Technol., 99: 1538-1543.

http://dx.doi.org/10.1016/j.biortech.2007.04.021.

16. Kubojima, Y.; Okano, T.; Ohta, M., 2000: Bending strength of heat-treated wood. J. Wood Sci., 46: 8-15.
17. Kubojima, Y.; Okano, T.; Ohta, M., 1998: Vibrational properties of Sitka spruce heat-treated in nitrogen gas. J. Wood Sci., 44: 73-77. https://doi.org/10.1007/BF00521878.

18. Oliveira, R. M.; Brisolari, A.; Sales, A.; Gonçalves, D., 2010: Wettability, Shrinkage and Color Changes of Araucaria angustifolia After Heating Treatment. Materials Research, 13 (3): 351-354. https://doi.org/10.1590/S1516-14392010000300012.

19. Perçin, O.; Uzun, O., 2014: Determination of bonding strength in heat treated some wood materials, SDU Faculty of Forestry Journal, 15: 72-76.

20. Petrissans, M.; Gerardin, P.; Elbakali, D.; Serraj, M., 2003: Wettability of heat treated wood. Holzforschung, 57: 301-307. http://dx.doi.org/10.1515/HF.2003.045.

21. Ross, R. J. (ed.), 2010: Wood handbook: Wood as an engineering material, General Technical Report FPL-GTR 190. U.S. Department of Agriculture, Forest Service, Forest Products Laboratory. Madison, WI.

22. Šernek, M.; Humar, H.; Kumer, M.; Pohleven, F. 2007 : Bonding of thermally modified spruce with PF and UF adhesives. In: Proceedings of the 5th COST E34 International Workshop. Bled-Slovenia, pp. 31-39.

23. Šernek, M.; Boonstra, M.; Pizzi, A.; Despres, A.; Gerardin, P., 2008: Bonding performance of heat-treated wood with structural adhesives. Holz Roh-Werkst., 66 (3): 173180. http://dx.doi.org/10.1007/s00107-007-0218-0.

24. Unsal, O.; Ayrilmis, N., 2005: Variations in compression strength and surface roughness of heat-treated Turkish river red gum. J. Wood Sci., 51: 405-409. http://dx.doi.org/10.1007/s10086-004-0655-x.

25. Weiland, J. J.; Guyonnet, R.; Gibert, R., 1998: Analysis of controlled wood burning by combination of TA, DSC and FTIR spectroscopy. Journal of Thermal Analysis and Calorimetry, 51 (1): 265-274. https://doi.org/10.1007/BF02719028.

26. Windeisen, E.; Strobel, C.; Wegener, G., 2007: Chemical changes during the production of thermotreated beech wood. Wood Sci Technol, 41 (6): 523-536. http://dx.doi.org/ 10.1007/s00226-007-0146-5.

27. ***TS 2472, 2005: Wood - Determination of density for physical and mechanical tests. Turkish Standards Institute, Ankara, Turkey (in Turkish).

28. ***TS 2474, 1976: Wood - Determination of Ultimate Strength in Static Bending. Turkish Standards Institute, Ankara, Turkey (in Turkish).

29. ***TS 2478, 1976: Wood-Determination of Modulus of Elasticity in Static Bending. Turkish Standards Institute, Ankara, Turkey (in Turkish).

30. ***TS 2595, 1997: Wood-Determination of Ultimate Stress in Compression Parallel to Grain. Turkish Standards Institute, Ankara, Turkey (in Turkish).

31. ***TS 3459, 2012: Wood-Determination of ultimate shearing stress parallel to grain. Turkish Standards Institute, Ankara, Turkey (in Turkish).

\section{Corresponding address:}

Assoc. Prof. ERGÜN GÜNTEKİN, Ph. D.

Department of Forest Products Engineering

Faculty of Forestry

Suleyman Demirel University

Isparta, TURKEY

e-mail: ergunguntekin@sdu.edu.tr 